\title{
Research on the problems of the development of cross-border E-business under the new situation
}

\author{
Fang $\mathrm{Zhu}^{1, \text { a }}$, Huajie $\mathrm{Mu}^{2, \mathrm{~b}}$ \\ ${ }^{1}$ Shandong Industrial Technician College, Weifang 261000, China; \\ ${ }^{2}$ Shandong Industrial Technician College, Weifang 261000, China. \\ azhufang151@163.com, 'bmuhuajie@126.com
}

Keywords: cross-border E-business, One Belt and One Road, problem, strategy.

\begin{abstract}
With the deep development of globalization of trade and the detailed implementation of the strategic policy of "One Belt and One Road" in China, the status of cross-border E-business in China's foreign trade is increasingly prominent. As the breakthrough point of the current situation of China's cross-border E-business, this article concluded the question needed to be solved in the in the process of development of cross-border E-business in China under the new situation and put forward some corresponding suggestions.
\end{abstract}

\section{Introduction}

Cross-border E-business is an method of international trade by electronic commerce. With the rapid development of China's Internet process in recent years, E-business enterprises have sprung up to take root in the domestic E-business market, while the individual users and E-business companies have concentrated on the overseas market. Under the background of the era of global economic integration, they make full use of the price differential caused by the international division of labor to carry out the cross-border business.

In the past ten years, China's E-business application model have undergone a qualitative change in terms of the traditional form of shopping malls, stores, other offline shopping, the current common PC and the mobile terminal online shopping, which promoted the integration of informatization and economic globalization. E-business has blended into Chinese life and been changing Chinese consumption custom and lifestyle profoundly.

But, the rapid development of E-business industry are facing with enormous challenges. How to satisfy the growing consumer's demands, reform the electricity business sales model and find a new industry growth point have become an important test under the current mature mode. Then "cross-border E-business" is definitely the core engine to pull China's industry further growth in the future.

\section{The problem of the cross-border E-business's development are faced}

\subsection{Buying guide is not enough}

With the improvement of China's national income levels and China yuan's exchange rate stronger, Chinese consumer has become the world's most of the purchasing power of consumers, which are reflected obviously in the aspect of Chinese tourists overseas consumption. But the current cross-border E-business consumer groups' buying guide were not enough and existed many problems. In addition, the E-business operators and consumers' spending habits have traditionally focused on the domestic market and did not adapt to the trend of the development of the cross-border E-business, which also need to be further serviced and guided.

\subsection{The business processes are complex}

It is very complicated that Cross-border E-business in the import and export business processes from purchasing goods, transport, the cargo customs clearance and cargo distribution, which require the buyers and sellers and cross-border E-business practitioners to have high capacity and rich 
experience. The key is how to do cross-border supply chain management only from the point of the view of operation. At present, the two most important problems of the cross-border supply chain management are the management of the overseas' suppliers and cross-border logistics. Because the foreign manufacturers' capacity is limited and do not have the enough energy to take care of the Chinese market, while the famous international products already have the fixed domestic sales channels, which leads to the difficult of investment attraction. The cargo clearance speed and the goods circulation speed also affect the consumer's experience significantly in the cross-border logistics management. These business process are so complicated and difficult, on the one hand, which restricted the cross-border E-business operators' large-scale management, on the other hand, which also limits the cross-border consumers' consumption.

\subsection{The policy system of supervision is not clear}

Nowadays, the general administration of customs has approved seven cities for cross-border electricity imported pilot, and set off a series of import policies about retail E-business, which reduced the burden of the cross-border business operator and improved the consumer's shopping experience. At present, on the one hand ,only the customs system introduced a special policy, while the other relevant authorities have not yet to do it, such as the general administration of quality supervision and foreign exchange management. On the other hand, it is not entirely consistent in the operation of the specific provisions about the seven cross-border E-business pilots. The current regulatory system is also influenced the development of cross-border E-business seriously since it is not accordant and certain. Thus, the operators have to response to this uncertainty risk by carefully and taking conservative attitude.

\subsection{The environment of the cross-border E-business market remains to be improved}

At present, China's poor cross-border E-business market environment has affected the further development of the industry, whose main problems include:

(1)The imperfect web sites of the cross-border E-business, the language barrier, different consumption habits and other reasons, so the current cross-border E-business websites are given priority to the foreign websites.

(2)The promotion channel is not smooth because the website platform is not mature and the domestic websites are in a construction and development period, it mainly rely on the traditional E-business platform in China such as Taobao whose promotion is in form of overseas online shopping and have poor pertinence.

(3)The issue of cross-border payment has effected the management of E-business because foreign exchange control policies are tight.

(4) International logistics relied by cross-border E-business also were restricted by the backward of the traditional customs policy and the customs warehouse regulation policy. Although, China has become the world power in terms of economic output and trade volumes, in the international trade rules, especially on the set of the cross-border electricity trade rules, our voice is still limited, which also has restricted the further development of cross-border E-business industry.

\section{The strategy of accelerating the development of cross-border E-business}

\subsection{The reform of the cross-border E-business customs supervision system}

The cross-border E-business customs supervision system has given priority to the customs.The leap-forward development of the cross-border E-business should reform the customs' supervision system and mode firstly and realize the cross-border E-business platform and the customs supervision platform interconnection. To carry out the OBAOR strategic, to improve customs supervision mechanism and to adapt to the new demands of it, the cross-border E-business have developed through effective measures. For example, the government can reduce the enterprises' burden on the mode of centralized taxation and selective taxation. The exports of E-business could sue a special statistics to resolve the problems of uncalculated about the import and export of goods. It is convenient that the E-business enterprises carries out the export tax rebates and reduces the operating costs. 


\subsection{The construction of cross-border E-business industry chain}

It is of significant that we should construct the cross-border E-business industry chain, shorten the cycle of cross-border shopping and improve the cross-border consumption experience. Currently, the cross-border E-business process is relatively complex and the logistics cycle even reached more than 2 months, which severely reduces the consumption of consumers experience. The main methods of the constriction of cross-border E-business industry clusters includes the free trade zone, the bonded zone and experimental area, which can give the convenient measures and package of services about international logistics system and storage system for cross-border electricity enterprises.

\subsection{Improving the development environment of cross-border E-business}

Comparing with the foreign market, the current urgent matter is that we should optimize the environment of China's cross-border E-business dealer market since it started lately in our country and the market environment is poorer. Next, we should perfect the national cross-border E-business service pilots and make them realized that cross-border electricity market have rich profit space. Accelerating the construction of cross-border E-business platform, the current E-business sites construction will be transformed from a single information platform to the comprehensive trading platform which includes the overseas promotion, brand building, transaction support, online payment, online logistics, after-sales service and online disputes handing . We can improve the consumers' experience though grasping the domestic and overseas market environment, researching the consumers' preferences, improving the suppliers' diversity and enhancing the consumers' experience. It is essential to learn and absorb the foreign mature experience of the cross-border E-business, actively participating in the electronic commerce trade rules and improving China's international cross-border E-business power. We will accelerate the establishment of import and export credit system, strength the industry regulation and improve the market order and reputation of the E-business enterprises and products.

\subsection{Providing the convenient financing channel of the cross-border E-business}

At present , the developing cross-border E-business needs a lot of financial support, so which must add the financing channels. Our government should encourage the domestic financial institutions to provide cross-border payment services for cross-border E-business, strength the payment supporting service, improve the strength of cooperation with overseas third-party payment institutions and enhance the ability of China's E-business enterprises' cross-border settlement services. It is urgent that the relevant departments put together the third-party payment platform into the cross-border electronic payments and improve the convenience and efficiency of cross-border payment. Finally, the government should establish a special national financial policy for the medium, small and micro cross-border E-business enterprise, and provide the micro-finance services conveniently.

\subsection{To speed up the training of specialists in the field of cross-border E-business}

With the rapid development of the cross-border E-business industry in recent years, we needs many more higher quality managers cultivated by the higher vocational education adopted to the development of E-business. We should integrate the cross-border E-business industry demands closely and adopt the mode of university-enterprise cooperation and order training .

\section{Summary}

To sum up, the implementation of the strategy of "One Belt And One Road" has accelerated the development of cross-border E-business.By creating the era opportunity, optimizing the market environment, constructing the international industrial chain, reforming the regulatory measures and so on, the cross-border E-business industry in China will be bound to usher in a new round, which also has great realistic significance in terms of improving the trade structure and the quality of development in China . 


\section{References}

[1]. Guangcheng Xing. Silk roads of land and sea:Strategic channels to the world, J. People Tribune. (2014) No.7, p. 92-97.

[2]. Xiaoxing Ding. Analysis of the Strategic Importance and Feasibility of the Silk Road Economic Belt-Also on Promoting Comprehensive Cooperation between China and Central Asia, J. Frontiers. (2014) No. 2, p. 71-78.

[3]. Lei Wu. The New Silk Road: Broadening China-Mideast Relationship, J. West Asia and Africa. (2014) No. 3, p. 4-16.

[4]. Xincai Gao. The Silk Road Economic Belt and Passage Economy, J. China Business and Market. (2014) No. 4, p. 92-96.

[5]. Aijun Guo, Jinhuang Mao. A Strategic Study on the Spatial Diversity and Distribution of the Competitive Industries on the Silk Road Economic Belt, J. Journal of Lanzhou University(Social Sciences). (2014) No. 1, p. 40-49.

[6]. Huang Weiping. The New Silk Road Economic Belt and the New Development of Economic and Trade Pattern of China-EU, J. China Business and Market. (2014) No. 1, p. 84-90.

[7]. Tie Liu, Guihua Li, Hongliang Lu. The Mechanism of Impact of Online and Offline Process and Integrated Marketing Strategy on Brand Experience of Online Retailers, J. China Business and Market. (2014) No. 11, p. 51-57.

[8]. Bin Zhang, Xiaojun Liu, Tao Zhang. The Study of Current Situation and Operation Pattern of the Cross-border E-commerce Logistics in China, J. China Business and Market. (2015) No.1, p. 51-56.

[9]. Juanjuan Wang. Exploring the Development of Agricultural Products Cloud Logistics Based on E-commerce, J. China Business and Market. (2014) No. 11, p. 37-42.

[10]. Juanjuan Wang. The analysis of Logistics Development in E-commerce Era, J. China Business and Market. (2014) No. 3. p. 54-59.

[11]. Information on: www.cnnic.net.cn/hlwfzyj/hlwxzbg/hlwtjbg/201407/t20140721_47437.htm.

[12]. Information on: www.100ec.cn/zt/2013ndbg/. 